\title{
ON THE OUTSIDE SEEKING IN: MUST INTERVENORS DEMONSTRATE STANDING TO JOIN A LAWSUIT?
}

\author{
JULIET JOHNSON KARASTELEV
}

\begin{abstract}
INTRODUCTION
The law's traditional conception of a "case" has evolved from a discrete dispute between two adverse parties to a multiparty structure covering a range of related and often conflicting interests. ${ }^{1}$ The Federal Rules of Civil Procedure provide several avenues for expanding the involved participants in a case beyond a single plaintiff and single defendant to include other affected or interested parties. ${ }^{2}$ Intervention under Rule 24 is the vehicle nonparties use to protect their interests from potential impairment by a court's adjudication of a dispute between the original parties. By allowing nonparties to intervene, Rule 24 lets them represent their interests and arguably improves the court's decisionmaking by allowing the presentation of different viewpoints and evidence. ${ }^{3}$ Courts may also benefit from granting mo-

Copyright (c) 2002 by Juliet Johnson Karastelev.

1. Susan Bandes, The Idea of a Case, 42 StAn. L. REV. 227, 250-55 (1990) (discussing Article III limits on who can participate in a case); see also Abram Chayes, The Role of the Judge in Public Law Litigation, 89 HARV. L. REV. 1281, 1282-84 (1976) (describing the federal courts move away from adjudicating bipolar private law disputes to sprawling multiparty litigation about constitutional and statutory rights).

2. See generally Sherman L. Cohn, The New Federal Rules of Civil Procedure, 54 GEO. L.J. 1204 (1966) (summarizing the 1966 amendments to the Rules that affected party structure, including joinder, intervention, and class action); Benjamin Kaplan, Continuing Work of the Civil Committee: 1966 Amendments of the Federal Rules of Civil Procedure (I), 81 HARV. L. REV. 356 (1967) (describing the major multiparty practice reforms to the Federal Rules of Civil Procedure in 1966).

3. See Ellyn J. Bullock, Note, Acid Rain Falls on the Just and the Unjust: Why Standing's Criteria Should Not Be Incorporated into Intervention of Right, 1990 U. ILL. L. REV. 605, 628 (1990) (arguing that intervenors perform a public service by presenting an issue from a different vantage point); Brian Hutchings, Note, Waiting for Divine Intervention: The Fifth Circuit Tries to Give Meaning to Intervention Rules in Sierra Club v. City of San Antonio, 43 VILL. L. REV. 693, 733-34 (1998) (noting that one rationale for liberal intervention is to improve the flow of relevant information to the court in making decisions that have far-reaching effects).
\end{abstract}


tions to intervene, because by including intervenors up front, they may be spared relitigation of the same issue.

A recent decision in the Ninth Circuit, United States $v$. City of Los Angeles, ${ }^{5}$ helps illustrate the concept of intervention. In the wake of a widely publicized scandal regarding the Los Angeles Police Department (LAPD)'s use of excessive force, false arrests, and improper search and seizures, the U.S. Department of Justice negotiated a resolution of these constitutional violations with the Los Angeles City Council, the Board of Police Commissioners, and the LAPD. ${ }^{6}$ Before the federal district court entered the consent decree, the police officers' union (the Police League) and community groups dedicated to police reform (the Community Intervenors) sought leave to intervene. ${ }^{7}$ Although the city defendants had already conceded liability and accepted the settlement terms, the court recognized the unique positions of these nonparties. The Police League had an interest in whether the consent decree would affect the terms and conditions of its members' employment. ${ }^{8}$ The Community Intervenors, who represented both victims of the unconstitutional police misconduct and community activists that had collaborated on past reform efforts, had an interest in the implementation of the consent decree. ${ }^{9}$ Intervention allows nonparties like these, with substantial interests in the outcome of a matter, to participate in an ongoing litigation if they meet the requirements of Rule $24 .^{10}$

A nonparty may demand to intervene as of right, under Rule 24(a), or seek permissive intervention under Rule 24(b). ${ }^{11}$ This Note focuses on intervention as of right, because the federal courts of appeals are split regarding its proper application. At first glance, Rule 24(a)(2) appears to be a straightforward multifactor test. ${ }^{12}$ Article III

4. See Alan Jenkins, Foxes Guarding the Chicken Coop: Intervention as of Right and the Defense of Civil Rights Remedies, 4 MiCH. J. RACE \& L. 263, 279-80 (1999) (discussing the benefit of disposing of all issues in a single lawsuit to avoid later lawsuits).

5. 288 F.3d 391 (9th Cir. 2002).

6. Id. at 396.

7. Id. at $396-97$.

8. Id. at 400 .

9. Id. at 397 .

10. The court granted the Police League's motion to intervene as of right, and remanded to the lower court the question of whether the Community Intervenors should be granted permissive intervention. Id. at 404.

11. FED. R. CIV. P. 24.

12. The first clause of Rule 24 , which is not controversial, permits intervention when "a statute of the United States confers an unconditional right to intervene." FED. R. CIV. P. 
standing $^{13}$ is neither implicated by the bare language of Rule 24 nor referenced in the few Supreme Court decisions applying it. ${ }^{14}$ Nonetheless, the federal courts of appeals are split over whether, in addition to satisfying the four-part test of Rule 24(a)(2), an intervenor must also prove that he has a justiciable case or controversy with his adversary. ${ }^{15}$ There is also no consensus among the circuits about whether standing is equivalent to Rule 24(a)(2)'s elusive "interest" requirement. ${ }^{16}$

In this Note, I argue that a prospective intervenor should meet Article III standing requirements, in addition to Rule 24(a)'s test, only when the intervenor has or could be subject to a claim to relief. ${ }^{17}$ If instead, the intervenor merely seeks to protect an interest that might be impaired by the outcome of a lawsuit, rather than present or defend against a legal claim, then satisfying Rule 24(a)'s factors should be sufficient. ${ }^{18}$

24(a)(1). The second clause requires that the applicant (1) make a timely motion; (2) claim an interest relating to the subject of the lawsuit; (3) allege a likely impairment of his interest if the lawsuit proceeds without him; and (4) convince the court that an existing party to the lawsuit cannot adequately represent his interests. FED. R. CIV. P. 24(a)(2).

13. See Friends of the Earth, Inc. v. Laidlaw Envtl. Servs., Inc., 528 U.S. 167, 180-81 (2000), for the Supreme Court's most recent exposition of Article III's standing requirements, i.e., that

a plaintiff must show (1) it has suffered an "injury in fact" that is (a) concrete and particularized and (b) actual or imminent, not conjectural or hypothetical; (2) the injury is fairly traceable to the challenged action of the defendant; and (3) it is likely, as opposed to merely speculative, that the injury will be redressed by a favorable decision.

14. See, e.g., Trbovich v. United Mine Workers, 404 U.S. 528, 538 (1972) (analyzing intervention of right by the Rule's literal terms without recourse to Article III standing analysis); Donaldson v. United States, 400 U.S. 517, 527 (1971) (same); Cascade Natural Gas Corp. v. El Paso Natural Gas Co., 386 U.S. 129, 134 (1967) (same).

15. In other words, if the intervenor seeks to join the plaintiff's side in a case (plaintiffintervenor), he would have to demonstrate Article III standing. If the intervenor seeks to support the defendant's position (defendant-intervenor), the question is whether the plaintiff has a justiciable case with the defendant-intervenor.

16. See infra Part II for discussion of the circuit split.

17. Relief is used as shorthand for the range of legal actions an intervenor might pursue, or that might be pursued against him, such as damages, injunctions, declaratory judgments, etc.

18. For example, in United States v. City of Los Angeles, the DOJ and the Police League did not have legal claims against one another, but there was a risk that the consent decree negotiated with the official city parties could impact on the Police League's members' interests. See supra notes 5-10 and accompanying text. In such a situation, I argue that the Police League should not have to demonstrate that it has a justiciable case with the DOJ. By contrast, if the Community Intervenors sought relief, such as damages, from the City for the unconstitutional police misconduct, then they should be required to demonstrate Article III standing. 
In Part I of this Note, I provide a brief primer on Article III standing and summarize the roots and interpretation of Rule 24. In Part II, I lay out the current circuit split on the relationship between intervention and standing. In Part III, I criticize the proposition that Article III standing should always be an additional prerequisite to intervention. Likewise, in Part IV, I argue that interpreting the "interest" requirement of Rule 24(a)(2) as equivalent to Article III standing is equally misguided. Finally, in Part V, I propose that Article III standing is an appropriate additional test for intervenors when they seek, or may be subject to, some form of relief but not when they are merely attempting to protect an interest.

\section{The Constitutional AND Civil Procedure UnderPinnings OF THE CIRCUIT SPLIT: ARTICLE III STANDING AND RULE 24'S INTERVENTION OF RIGHT}

In order to assess the relevance, if any, of Article III standing to intervention as of right, it is first necessary to understand the purposes and operation of both doctrines. To that end, in this Part, I present the key concepts of Article III standing and intervention, including their respective tests.

\section{A. Article III Standing in a Nutshell}

Standing is the familiar shorthand for "whether the plaintiff has made out a 'case or controversy' between himself and the defendant within the meaning of Art[icle] III."19 The black letter rule is that in order to satisfy Article III, a plaintiff must show that he has suffered, or will suffer, a distinct and palpable injury that is caused by the defendant's conduct and that is redressable by the court. ${ }^{20}$ In addition to the constitutional requirements of injury, causation, and redressability, the standing doctrine encompasses several prudential considerations. $^{21}$ Key among them is the prohibition on generalized griev-

\footnotetext{
19. Warth v. Seldin, 422 U.S. 490, 498 (1975).

20. Valley Forge Christian Coll. v. Ams. United for Separation of Church \& State, Inc., 454 U.S. 464, 472 (1982) (summarizing the "irreducible minimum" that a party must show to gain access to the federal courts); see also William A. Fletcher, The Structure of Standing, 98 YALE L.J. 221, 222 (1988) (outlining the "numbingly familiar" black letter doctrine of standing).

21. Valley Forge Christian Coll., 454 U.S. at 474 ("Beyond the constitutional requirements, the federal judiciary has also adhered to a set of prudential principles that bear on the question of standing.").
} 
ances-"abstract questions of wide public significance" $" 22$-in order "to limit the role of the courts in resolving public disputes.",

In the Warren Court era, federal courts were relatively lenient toward plaintiffs that sought to litigate shared public interests or constitutional values, even when they were not more demonstrably injured than members of the general population. ${ }^{24}$ By contrast, the Rehnquist Court has since made clear in Lujan v. Defenders of Wildlife $e^{25}$ that a plaintiff must have suffered "an invasion of a legally protected interest which is . . concrete and particularized,", must be "'directly affected apart from [his] 'special interest in th[e] subject." "27 Lujan thus elevated the ban on generalized grievances from a prudential concern to a constitutional mandate. ${ }^{28}$ Leaving aside the merits or constitutional validity of a stringent injury requirement for standing, applying the test in the intervention context is contrary to Rule 24's purpose of addressing anticipated injuries. ${ }^{29}$

The Lujan decision was also important for its reaffirmation that the standing requirements of Article III are immutable; that is, Congress may not legislate around the concrete injury requirement. The Court rejected Congress's attempt in the Endangered Species Act (ESA) to convert an undifferentiated public interest in the executive branch's compliance with ESA procedures into an individual right vindicable in the courts. ${ }^{30}$ In other words, even if Congress created a legal right that was subsequently invaded, that violation alone would not constitute an injury for the purposes of Article III. ${ }^{31}$ The injury would still need to meet Article III constitutional standards of concreteness and distinctness. Lujan thus raised to new heights the $\mathrm{Su}$ -

\footnotetext{
22. Warth, 422 U.S. at 500.

23. Id.

24. See, e.g., Flast v. Cohen, 392 U.S. 83, 100-01 (1968) (finding that a taxpayer had standing to protest federal subsidies to parochial schools); Fletcher, supra note 20, at 227-28 (discussing the increase in public law litigation in the 1960s and 1970s).

25. 504 U.S. 555 (1992).

26. Id. at 560 .

27. Id. at 563 (quoting Sierra Club v. Morton, 405 U.S. 727, 735, 739 (1972)).

28. ERWIN CHEMERINSKY, FEDERAL JURISDICTION 95 (3d ed. 1999) (discussing generalized grievances as a constitutional bar).

29. See infra Part IV.

30. Lujan, 504 U.S. at 576.

31. See Gene R. Nichol, Jr., Justice Scalia, Standing, and Public Law Litigation, 42 DuKE L.J. 1141, 1146-47 (1993) (remarking on the Court's surprising holding that a statute's conferral of standing on a potential plaintiff was insufficient).
} 
preme Court's interpretation of Article III's standing requirements as an "irreducible constitutional minimum.",32

In addition to hardening the concrete injury requirement, some on the Court, led by Justice Scalia, would like to tighten the redressability prong of the Article III standing inquiry. ${ }^{33}$ Under current law, a plaintiff need not show narrow tailoring of the remedy to his injury. ${ }^{34}$ But if it were otherwise, a requirement that intervenors demonstrate that the court could fashion a precise remedy would be a substantial barrier to their participation in the suit because their interest is often indirect.

The Rehnquist Court's strict interpretation of the concrete injury requirement, and perhaps a similarly tough treatment of the redressability requirement in the future, is incompatible with the forms of litigation produced by the expansion of class actions, intervention, and joinder under the Federal Rules of Civil Procedure discussed in Section B. ${ }^{35}$

\section{B. The Text and Purpose of Rule 24(a)(2)}

In the vast majority of cases, the question of whether a prospective intervenor is required to have Article III standing arises in motions to intervene as of right under Rule 24(a)(2). In relevant part, the Rule provides that

[u]pon timely application anyone shall be permitted to intervene in an action... when the applicant claims an interest relating to the property or transaction which is the subject of the action and the applicant is so situated that the disposition of the action may as a prac-

32. Lujan, 504 U.S. at 560.

33. In Lujan, Justices Rehnquist and Thomas joined Justice Scalia in arguing for a stringent test that any remedial action taken by the court would precisely redress the plaintiff's alleged injury. 504 U.S. at 558-61.

34. See Friends of the Earth, Inc. v. Laidlaw Envtl. Servs., Inc., 528 U.S. 167, 185-186 (2000) (holding, over a vigorous dissent by Justice Scalia, that generalized civil penalties for violations of the Clean Water Act could satisfy the redressability requirement).

35. See The Supreme Court, 1999 Term-Leading Cases, 114 HARV. L. REV. 329, 336 (2000) (commenting that the Supreme Court's recent standing jurisprudence limits the federal courts to a private law model that is inconsistent with congressionally created avenues for public law litigation by statute or through amendments to the Federal Rules of Civil Procedure. For an early recognition of the tension between a standing formula that attempts to limit who may sue and intervention's open invitation to persons with a significant ("a weasel word") interest at risk to participate in a lawsuit, see also Chayes, supra note 1, at 1290-91. 
tical matter impair or impede the applicant's ability to protect that interest. ${ }^{36}$

The above language dates to the 1966 amendments to the main Rules governing party structure, which, in addition to Rule 24 , included Rule 19 (necessary party joinder) and Rule 23 (class actions). ${ }^{37}$ The changes were premised on the belief that it was more efficient and equitable to settle all issues arising from a single set of circumstances in one lawsuit. ${ }^{38}$ Thus, the revised Rules gave courts pragmatic tools for facilitating multiparty lawsuits-often over public interest controversies rather than private disputes. ${ }^{39}$ Rule 24(a)(2) and Rule 19(a)(2)(i $)^{40}$ shared the similar objective of reeling in nonparties with interests that might be affected by resolution of a dispute before the court. Although both provisions used identical language to describe the nature and risk of impairment to an interest that might warrant intervention or necessary joinder, neither articulated a definition of "interest." "41

At a minimum, the revision to Rule 24 was intended to repudiate the earlier narrow conception of "interest" as an interest in specific property before the court, or of defining "impairment" as being legally bound as a matter of res judicata. ${ }^{42}$ Nonetheless, Professor Benjamin Kaplan, one of the drafters of the amendments, wrote that the altered phrasing of the interest requirement was still informed by the

\footnotetext{
36. FED. R. CIV. P. 24(a)(2) (emphasis added).

37. Amendments to Rules of Civil Procedure, 39 F.R.D. 69, 87-109 (1966).

38. See Cohn, supra note 2, at 1204 (characterizing the purpose of the amended Rules as placing all substantive issues in a case before a court with minimal procedural restrictions). Judge Henry J. Friendly interpreted the 1966 amendments as a directive to the courts to be flexible in considering all competing and relevant interests in order to reach pragmatic solutions to a wide variety of intervention problems. United States v. Hooker Chem. \& Plastics Corp., 749 F.2d 968, 983 (2d Cir. 1984).
}

39. Carl Tobias, Standing to Intervene, 1991 WIS. L. REV. 415, 422-23 (describing how the 1966 amendments created a veritable renaissance in public law litigation).

40. See FED. R. CIV. P. 19(a):

A person ... shall be joined as a party in the action if ... (2) the person claims an interest relating to the subject of the action and is so situated that the disposition of the action in the person's absence may (i) as a practical matter impair or impede the person's ability to protect that interest....

41. In an early comment on the revision to the Rules, Professor David Shapiro argued that it was unlikely that federal courts of appeals would give "interest" the same construction in Rule 19 and Rule 24. See David L. Shapiro, Some Thoughts on Intervention Before Courts, Agencies, and Arbitrators, 81 HARV. L. REV. 721, 757 (1968).

42. Amendments to Rules of Civil Procedure, 39 F.R.D. 69, 109-11 (1966) (Advisory Committee's note). 
historic understanding of intervention ${ }^{43}$ - that the applicant demonstrate a "direct, substantial, legally protectable interest in the proceedings." ${ }^{\prime 4}$ Others rejected "a myopic fixation upon "interest,", ${ }^{45}$ arguing that Rule 24's test was "primarily a practical guide to disposing of lawsuits by involving as many apparently concerned persons as is compatible with efficiency and due process." ${ }^{46}$ The debate about the meaning of Rule 24's "interest" remains to this day, ${ }^{47}$ and the Supreme Court has not clarified the matter.

\section{The Supreme Court's Interpretations of Rule 24 "Interest"}

The Supreme Court's few Rule 24 decisions have not elucidated the criteria for evaluating whether an interest is sufficient to intervene. In its first interpretation of the amended Rule, in Cascade Natural Gas Corp. v. El Paso Natural Gas Co. ${ }^{48}$ the Court noted that the drafters intended it to be not only a restatement, but also, an amplification of the previous federal practice, and commented that therefore "some elasticity was injected; and the question is, how much." ${ }^{49} \mathrm{Be}-$ cause the intervenor's interests were "'at the heart of the controversy, ", ${ }^{50}$ the Court read the Rule broadly, thereby laying the groundwork for a liberal approach to applying the amended Rule. ${ }^{51}$

Greater clarity did not emerge from the Supreme Court's subsequent interpretation of Rule 24(a)(2) in Donaldson v. United States. ${ }^{52}$ In discussing the type of interest contemplated by the provision, the Court stated "[w]hat is obviously meant there is a significantly pro-

43. Kaplan, supra note 2, at 405 (implying that the Supreme Court's first interpretation of the revised Rule went beyond the weight of the case authority on what constituted an interest).

44. 7C Charles Alan Wright et Al., Federal Practice and Procedure $§ 1908$ (2d ed. 1986 \& Supp. 2002).

45. Smuck v. Hobson, 408 F.2d 175, 179 (D.C. Cir. 1969).

46. Nuesse v. Camp, 385 F.2d 694, 700 (D.C. Cir. 1967).

47. This debate has led at least one scholar to posit that "it well may be that this is a question not worth answering." 7C WRIGHT ET AL., supra note 44, § 1908 (Supp. 2002).

48. 386 U.S. 129 (1967).

49. Id. at 134 .

50. Id. at 135 (quoting Missouri-Kansas Pipe Line Co. v. United States, 312 U.S. 502, 506 (1941)).

51. Most scholars believe that the decision in Cascade should be held to its particular facts. See, e.g., Shapiro, supra note 41, at 730 ("[T] he apparent novelty of the rulings on intervention may have been largely a result of the Court's dissatisfaction with the substantive provisions of the [antitrust settlement] decree."); Tobias, supra note 39, at 433 (commenting that the Court wanted to facilitate intervention in a case that had national consequences and was also mindful that the would-be intervenor was the State of California).

52. 400 U.S. 517 (1971) 
tectable interest. ${ }^{, 53}$ Fifteen years later, in Diamond v. Charles, ${ }^{54}$ Justice O'Connor, in her concurring opinion, stated, “[c]learly, Donaldson's requirement ... calls for a direct and concrete interest that is accorded some degree of legal protection." ${ }^{, 55}$ As one commentator has noted, these explanations "raise[ ] more questions than [they] answer[ ], including how significant the interest must be, and by what means the interest must be protectable." ${ }^{, 56}$

Diamond is important not for Justice O'Connor's nebulous clarification of the meaning of "interest," but rather, because it represents the Court's only ruling that partially addressed a question that had begun to simmer amongst the federal courts of appeals- the relevancy, if any, of Article III standing to intervention. ${ }^{57}$ The Court was able to sidestep the issue ${ }^{58}$ because of Diamond's atypical procedural posture, in which the intervenor sought to appeal a decision accepted by the original party. The Diamond Court held that "an intervenor's right to continue a suit in the absence of the party on whose side intervention was permitted is contingent upon a showing by the intervenor that he fulfills the requirements of Art. III." ${ }^{, 59}$ The result is logical because, if the intervenor did not have standing, there would be no "case or controversy" before the court on appeal..$^{60}$ The federal cir-

53. Id. at 531 (emphasis added).

54. 476 U.S. 54 (1986).

55. Id. at 75 (O'Connor, J., concurring in part and concurring in the judgment).

56. Peter A. Appel, Intervention in Public Law Litigation: The Environmental Paradigm, 78 WASH. U. L.Q. 215, 263 (2000); see also Tobias, supra note 39, at 433 (observing that Justice O'Connor's clarification "provides little more guidance than the bare term interest" (internal quotation marks and citation omitted)).

57. Diamond, 476 U.S. at 68 n.21 (citing federal circuit court cases that "reached varying conclusions as to whether a party seeking to intervene as of right must himself possess standing").

58. Id. at 68-69 ("We need not decide today whether a party seeking to intervene before a district court must satisfy not only the requirements of Rule 24(a)(2), but also the requirements of Art. III.").

59. Id. at 68.

60. See Shapiro, supra note 41, at 753-54 ("Adding $C$ to a litigation between $A$ and $B$ may pose no problems under [A]rticle III ... but permitting $C$ to be the sole adversary of $B$ on appeal . . . certainly does give difficulty since there is no real controversy between $A$ and $C$."). 
cuits have applied the Diamond holding with ease. ${ }^{61}$ As for the more typical cases that are the subject of this Note-intervenors at the trial court level-the Court left unsettled "the precise relationship between the interest required to satisfy the Rule [24(a)(2)] and the interest required to confer standing."

\section{THE CIRCUIT SPLIT}

Despite the fact that neither the Supreme Court, nor the plain language or commentary to the amended Rule 24 , required that intervenors have standing, the D.C. and Eighth Circuits have reached the opposite conclusion, thereby creating a split with some of their sister circuits (the Second, Fifth, Sixth, Tenth and Eleventh), while other circuits have remained on the sidelines. In Part II, I outline this disagreement before analyzing its merits in Parts III and IV.

\section{A. The D.C. and Eighth Circuits Require that Intervenors Have Standing}

The D.C. Circuit was the first both to raise the issue of standing in the context of Rule $24^{63}$ and to definitively hold, in City of Cleveland v. Nuclear Regulatory Commission, ${ }^{64}$ that standing was a prerequisite for intervention. The court explained that "because a Rule 24

61. See, e.g., Idaho Farm Bureau Fed'n v. Babbitt, 58 F.3d 1392, 1398 (9th Cir. 1995) (stating that absent an appeal by the original defendant, the intervenors must have standing to pursue an appeal themselves); Associated Builders \& Contractors v. Perry, 16 F.3d 688, 693 (6th Cir. 1994) (holding that a trade association could not appeal a trial court decision that certain apprenticeship laws were preempted if the State as original defendant chose not to appeal); Yniguez v. Arizona, 939 F.2d 727, 731 (9th Cir. 1991) (stating that "“post-judgment intervention for purposes of appeal may be appropriate if the intervenors meet ... traditional standing criteria"” (quoting Legal Aid Soc'y of Alameda County v. Brennan, 608 F.2d 1319, 1328 (9th Cir. 1979))).

62. Diamond, 476 U.S. at 68. But see Appel, supra note 56, at 284-85 n.368 (arguing that the Court implied that standing was not required when it stated that Diamond, who the Court determined did not have standing, could have ridden piggyback on the state's appeal had the state pursued one).

63. In Southern Christian Leadership Conference v. Kelley, the court stated that not just "any" interest would do, but only a "legally protectable one," which was "in any case required by Article III." 747 F.2d 777, 779 (D.C. Cir. 1984). The court then decided that the would-be intervenor did not have an interest without using the three-factor standing test. $I d$. at 781 . Confusion in the D.C. Circuit as to the standard to intervene continued to reign, however. Compare Dimond v. District of Columbia, 792 F.2d 179, 191-94 (D.C. Cir. 1986) (holding that an insurance company was entitled to intervene after straightforward application of Rule 24(a)(2) with no mention of standing), with Cook v. Boorstin, 763 F.2d 1462, 1470 (D.C. Cir. 1985) ("[A]n intervenor of right, just like an ordinary plaintiff, must have standing.").

64. 17 F.3d 1515 (D.C. Cir. 1994). 
intervenor seeks to participate on an equal footing with the original parties to the suit, he must satisfy the standing requirements imposed on those parties. ${ }^{65}$ Although this rule was not consistently followed, ${ }^{66}$ the circuit recently affirmed that Article III standing was required to intervene, even when the statute in question included an open invitation to intervene by "communities, associations, corporations, firms, and individuals, whose interests are affected." ${ }^{, 67}$

Departing from its prior precedent, ${ }^{68}$ a divided panel of the Eighth Circuit established in Mausolf v. Babbitt" that the "Constitution requires that prospective intervenors have Article III standing to litigate their claims in federal court." ${ }^{70}$ The court reasoned that an "Article III case or controversy is one where all parties have standing, and a would-be intervenor, because he seeks to participate as a party, must have standing as well.,"71 The court stated that "[t]he standing requirement is, at its core, a constitutionally mandated prerequisite ... and 'an essential and unchanging part of the case-orcontroversy requirement of Article III." "72 Finally, the court noted that standing requirements helped ensure that federal courts did not become "a forum for the airing of interested onlookers' concerns, nor an arena for public-policy debates.",

\section{B. Majority Rule: Standing Not Required of Intervenors}

The Second, Fifth, Sixth, Tenth, and Eleventh Circuits hold that as long as the plaintiff has standing to litigate, and thus a valid Article

65. Id. at 1517 .

66. See, e.g., Am. Train Dispatchers Ass'n v. ICC, 26 F.3d 1157, 1162 (D.C. Cir. 1994) (granting an association's "motion to intervene without deciding whether it has Article III standing").

67. Rio Grande Pipeline Co. v. Fed. Energy Regulatory Comm'n, 178 F.3d 533, 539 (D.C. Cir. 1999) (quoting 28 U.S.C. $§ 2348$ (2000)). For criticism of this decision see Recent Case, Rio Grande Pipeline Co. v. FERC, 178 F.3d 533 (DC Cir. 1999), 113 HARV. L. REV. 1557, 1560-62 (2000) (chastising the court for abdicating its role as an adjudicator of public law disputes when the statute had "wide open and inviting" language for intervention).

68. See United States v. Union Elec. Co., 64 F.3d 1152, 1162 (8th Cir. 1995) (taking a liberal view of whether the litigation's outcome would impair the intervenor's interest); Planned Parenthood v. Citizens for Cmty. Action, 558 F.2d 861, 865 (8th Cir. 1977) (allowing a community group to intervene in the city's defense of a local ordinance because of its general interest in neighborhood property values).

69. 85 F.3d 1295 (8th Cir. 1996).

70. Id. at 1300 .

71. Id. (emphasis added).

72. Id. at 1301 (quoting Lujan v. Defenders of Wildlife, 504 U.S. 555, 560-61 (1992)).

73. Id. 
III case or controversy exists, prospective intervenors need not demonstrate standing. ${ }^{74}$ Their rationale is that it is the plaintiff who establishes the case or controversy, and as long as he or she does not drop out, other litigants may join or intervene in the matter if they meet the respective requirements of the Federal Rules that permit such actions. In addition, these circuits support the view that Rule 24 represents a policy choice-how to streamline related issues into a single lawsuit without it becoming unwieldy-rather than a deep constitutional question. ${ }^{75}$ In fact, courts often fail to reach the standinginterest conundrum because pragmatic concerns-like timeliness and inadequacy of representation-are embodied in the other prongs of Rule 24 and provide an easier basis for decisionmaking. ${ }^{76}$

\section{The Holdouts: Declining to Decide Whether Standing is a Necessity for Intervenors}

The First and the Ninth Circuits have not adopted a black letter rule, but dicta in their opinions indicates that fulfillment of the inter-

74. See Clark v. Putnam County, 168 F.3d 458, 463 (11th Cir. 1999) (noting that a lack of Article III standing is not dispositive in a motion to intervene); Ruiz v. Estelle, 161 F.3d 814, 830 (5th Cir. 1998) ("Article III does not require intervenors to independently possess standing where intervention is into a subsisting and continuing Article III case or controversy ...."); Associated Builders \& Contractors v. Perry, 16 F.3d 688, 690 (6th Cir. 1994) ("An intervenor need not have the same standing necessary to initiate a lawsuit in order to intervene in an existing ... suit where the plaintiff has standing."); U.S. Postal Serv. v. Brennan, 579 F.2d 188, 190 (2d Cir. 1978) ("The existence of a case or controversy having been established as between the Postal Service and the Brennans, there was no need to impose the standing requirement upon the proposed intervenor.").

75. Coalition of Ariz./N.M. Counties for Stable Econ. Growth v. Dep't of Interior, 100 F.3d 837, 841 (10th Cir. 1996) (quoting Nuesse v. Camp, 385 F.2d 694, 700 (D.C. Cir. 1967)). Ironically, Chief Judge Bazelon and Judge Leventhal of the D.C. Circuit first articulated the pragmatic approach to Rule 24 , see supra notes $45-46$ and accompanying text, while that circuit now takes a constitutional approach to the issue.

76. See, e.g., United States v. City of Miami, 278 F.3d 1174, 1175, 1179 (11th Cir. 2002) (affirming the denial of intervention to a community police association in an employment discrimination suit against the city, because the U.S. government adequately represented its interests); Kleisser v. U.S. Forest Service, 157 F.3d 964, 969-71 (3d Cir. 1998) (summarizing the pragmatic fact-specific inquiries that courts have followed in a wide variety of intervention cases); Bethune Plaza, Inc. v. Lumpkin, 863 F.2d 525, 531 (7th Cir. 1988) (cutting short a discussion of the relevance of standing to intervention because Rule 24 presented two independently sufficient obstacles to the intervenor-its interests were not impaired and they were adequately represented); Katharine Goepp, Note, Presumed Represented: Analyzing Intervention as of Right When the Government is a Party, 24 W. NEW ENG. L. REV. 131, 155 (2002) (noting that some circuits presume adequate representation when the government is involved in a case, partly in the interests of judicial economy and simplicity). 
est requirement usually means that standing is also met. ${ }^{77}$ By conflating the Article III standing test to having a "sufficient stake in the controversy," the First Circuit finds that it is largely interchangeable with Rule 24's "interest" concept. ${ }^{78}$ Similarly, the Ninth Circuit, when it has acknowledged the circuit split at all, has stated that its test of the strength of the interest of the intervenor captures the principle of standing. ${ }^{79}$ A recent Ninth Circuit case, however, ignored the split entirely, and analyzed an intervenor's motion according to policy considerations of "efficient resolution of issues and broadened access to the courts. ${ }^{" 80}$ Neither the Third nor the Fourth Circuit have expressly acknowledged or squarely addressed the circuit split. ${ }^{81}$

Finally, the Seventh Circuit's stance on the relationship between Article III standing and intervention is difficult to characterize. The circuit's most prominent judges have opined on opposite sides of the

77. See Southwest Ctr. for Biological Diversity v. Berg, 268 F.3d 810, 821 n.3 (9th Cir. 2001) (acknowledging that standing is "at least implicitly addressed by [the court's] requirement that the applicant must assert an interest relating to the property or transaction which is the subject of the action" (quoting Portland Audubon Soc'y v. Hodel, 866 F.2d 302, 308 n.1 (9th Cir. 1989))); Cotter v. Mass. Ass'n of Minority Law Enforcement Officers, 219 F.3d 31, 34 (1st Cir. 2000) ("[I]n the ordinary case, an applicant who satisfies the 'interest' requirement of the intervention rule is almost always going to have a sufficient stake in the controversy to satisfy Article III as well.").

78. See Daggett v. Comm'n on Governmental Ethics \& Election Practices, 172 F.3d 104, 110 (1st Cir. 1999) ("Although the two are not identical, the 'interest' required under Rule 24(a) has some connection to the interest that may give the party a sufficient stake in the outcome to support standing under Article III.").

79. Portland Audubon Soc'y v. Hodel, 866 F.2d 302, 308 n.1 (9th Cir. 1989) (declining to incorporate an independent standing inquiry into the circuit's test for intervention but noting that standing is implicitly addressed by Rule 24 's interest requirement).

80. United States v. City of Los Angeles, 288 F.3d 391, 398 (9th Cir. 2002) ("By allowing parties with a practical interest in the outcome of a particular case to intervene, we often prevent or simplify future litigation involving related issues; at the same time, we allow an additional interested party to express its views before the court." (quoting Forest Conservation Council v. U.S. Forest Serv., 66 F.3d 1489, 1496 n.8 (9th Cir. 1995))).

81. In McKay v. Heyison, 614 F.2d 899 (3d Cir. 1980), the court appeared to assume that an intervenor must have standing, and analyzed his motion accordingly, ultimately holding that he had standing, even though his injury was speculative in nature. Id. at 905 . The court has not, however, established a rule since the circuit split emerged. The Fourth Circuit has also not addressed the circuit split, but in a decision involving permissive intervention, noted that "possession of Article III standing is interwoven into the very concept of plaintiff status .... A permissive intervenor without standing may continue to be a party so long as the suit is kept alive by the plaintiff." Shaw v. Hunt, 154 F.3d 161, 166 (4th Cir. 1998) (emphasis added). 
issue. ${ }^{82}$ At one point, when the standing hurdle was perceived as more liberal and less rigorous than the Rule 24 interest requirementwhich is no longer true-the court held that "[t]he interest of a proposed intervenor ... must be greater than the interest sufficient to satisfy the standing requirement." ${ }^{, 3}$ In another opinion, the circuit appeared to take it as a given that intervenors demonstrate standing. ${ }^{84}$ In yet another decision, the court noted that the interest required to intervene was equivalent to that required for standing. ${ }^{85}$ Perhaps recognizing the confusion in its case law, the Seventh Circuit's most recent opinions avoid the question altogether. ${ }^{86}$

The circuits that have taken a stance on whether standing should be required of intervenors present it as a black-or-white choice. In Part III, I evaluate the position that intervenors must universally demonstrate Article III standing in addition to meeting Rule 24(a)(2)'s test. I analyze the alternative use of standing - as a proxy for Rule 24(a)(2)'s interest requirement-in Part IV. Finally, in Part $\mathrm{V}$, I propose that instead of a one-size-fits-all rule, a more nuanced approach to Article III standing and intervention is called for. Specifically, intervenors who either seek relief, or are at risk of being subject to relief by one of the parties, should demonstrate Article III standing. By contrast, intervenors who want to protect an interest should be held to the literal test of Rule 24(a)(2), and courts should make greater use of their existing discretion to tailor their participation in litigation to ensure that they do not ambush the case.

82. Judge Frank Easterbrook speculated in Bethune Plaza, Inc. v. Lumpkin, 863 F.2d 525, 531 (7th Cir. 1988), that where a prospective intervenor "could not have initiated this suit . . . it seems to follow that [he] may not intervene either." Judge Richard Posner, in Solid Waste Agency of N. Cook County v. U.S. Army Corps of Eng'rs, 101 F.3d 503, 507 (7th Cir. 1996), noted that the best rationale for intervention was where the intervenor could not initiate his own suit but had an interest that might be harmed.

83. United States v. 36.96 Acres of Land, 754 F.2d 855, 859 (7th Cir. 1988).

84. See Solid Waste Agency of N. Cook County, 101 F.3d at 507 (7th Cir. 1996) ("The threatened injury would give him the minimal standing required by Article III, which our court requires of any intervenor.").

85. See Transamerica Ins. Co. v. South, 125 F.3d 392, 396 n.4 (7th Cir. 1997) ("Any interest of such magnitude [to satisfy Rule 24(a)(2)] is sufficient to satisfy the Article III standing requirement as well.").

86. See Reid L. v. Ill. State Bd. of Educ., 289 F.3d 1009, 1017-20 (7th Cir. 2002) (denying intervention by analyzing Rule 24's requirements with no reference to Article III standing); Sokaogon Chippewa Cmty. v. Babbitt, 214 F.3d 941, 946 (7th Cir. 2000) (declining to "explore further what the outer boundaries of standing to intervene might be"). 


\section{STANDING AS AN ADDITIONAL REQUIREMENT FOR INTERVENORS AS OF RIGHT}

The point of contention between the Eighth and D.C. Circuits on the one hand, and the Second, Fifth, Sixth, Tenth, and Eleventh Circuits, on the other, is whether standing should be incorporated into intervention cases as an additional requirement. In other words, should an intervenor be required to satisfy Article III standing (injury-in-fact, causation, and redressability), as well as the four factors of Rule 24(a) (timeliness, interest, impairment, and inadequacy of representation)? The first rationale for this burden is that the Constitution mandates that all parties to litigation have standing, ${ }^{87}$ otherwise, if "joined by intervenors who lack standing, [it] is-put bluntly-no longer an Article III case or controversy." 88 The second rationale is that, if intervenors seek to participate in a case with the full procedural rights of parties, then they should be held to the same test for parties. ${ }^{89}$ Careful analysis of these rationales reveals the limitations of the former, and the merits of the latter.

\section{A. Intervenors Without Standing Threaten The Integrity Of An Article III Case}

The Eighth Circuit's decision in Mausolf v. Babbitt contains the fullest explication of the proposition that all parties, including intervenors, must have Article III standing, or else the case or controversy requirement is not met and the federal court lacks jurisdiction. ${ }^{90}$ The Mausolf court recognized that Rule 24(a)(2) promotes the efficient "use of judicial resources by allowing persons, who might otherwise have to bring a lawsuit on their own to protect their interests ... to join an ongoing lawsuit instead." "B1 But it held that regardless of the pragmatic benefits of Rule 24, "Congress cannot circumvent Article III's limits on the judicial power." 92 Paralleling the Supreme Court's

87. See supra notes 70-72 and accompanying text.

88. Mausolf v. Babbitt, 85 F.3d 1295, 1300 (8th Cir. 1996).

89. Bldg. \& Constr. Trades Dep't v. Reich, 40 F.3d 1275, 1282 (D.C. Cir. 1995) (reaffirming the circuit rule that intervenors who wish to participate on "equal footing" with the original parties must satisfy Article III standing).

90. Mausolf, 85 F.3d at 1301. For a full description of the merits of the lawsuit and its complex procedural history, see generally Rebecca Williams, Comment, Winter Wonderland: Intervention, Endangered Species and Snowmobiling in Voyageurs National Park, 5 Mo. ENVTL. L. \& POL'Y REV. 165 (1998).

91. Mausolf, 85 F.3d at 1300.

92. Id. 
Lujan reasoning that Congress could not bypass Article III standing requirements by statute, the Mausolf court held that Congress could not evade Article III through a Federal Rule of Civil Procedure. ${ }^{93}$ Thus, to the Mausolf court, it is immaterial that Rule 24(a)'s language does not mention standing, because it is elementary that standing is mandatory for entry into the federal courts. ${ }^{94}$ The Mausolf court also justifies its position on prudential grounds - that barring intervenors with mere interests helps prevent "the conversion of [federal] courts . . . into judicial versions of college debating forums." 95

While no one contests that federal jurisdiction is predicated on the existence of an Article III case or controversy, many bristle at the Eighth and D.C. Circuits' novel extension of standing requirements from a plaintiff's hurdle to a test for "all parties" ${ }^{96}$ involved in the lawsuit. ${ }^{97}$ First, other circuits and commentators point out that federal jurisdiction vests once the plaintiff has demonstrated standing, and the addition of other parties does not rob a case of its Article III status. Second, if allowing a party without standing to intervene under Rule 24(a) destroys the case, then, logically, necessary parties joined under the identically phrased Rule 19 must also prove standing or the case implodes, a consequence so far ignored by both the courts and legal commentators. Likewise, courts could not grant permissive intervention under Rule 24(b) without testing for standing, a position no court has adopted.

1. Only Plaintiffs Must Meet Article III Standing Requirements. Commentators who have addressed the merits of the Eighth Circuit's constitutional analysis contend that federal courts have a justiciable case or controversy, provided that one party has standing to sue, even

93. Id.

94. Michael K. Horn, Case Note, Standing in When the Government Bows Out: Mausolf v. Babbitt, 3 Great Plains NAT. Resources J. 72, 81 (1998) (discussing the Eighth Circuit's pronouncement that Rule 24 is "only applicable after intervenors have satisfied the Constitutional prerequisites").

95. Mausolf, 85 F.3d at 1301 (quoting Valley Forge Christian Coll. v. Ams. United for Separation of Church \& State, Inc., 454 U.S. 464, 473 (1982)).

96. Id. at 1300 .

97. Ruiz v. Estelle, 161 F.3d 814, 830 (5th Cir. 1998) (criticizing the D.C., Seventh, and Eighth circuits for offering little justification for their "new requirement" that intervenors "possess standing as a matter of constitutional law"); see also Bullock, supra note 3, at 642 ("[A]pplication of standing to an intervention applicant and a defendant is a gigantic extension of standing doctrine."); Recent Case, supra note 67, at 1560 (arguing that by "expanding the standing requirement to cover any party seeking to intervene," the D.C. Circuit is failing in its adjudication of public interest disputes (emphasis added)). 
if other participants lack standing. ${ }^{98}$ As Professor David Shapiro explains, "[p]erhaps it should go without saying, but ... there is a difference between the question whether one is a proper plaintiff or defendant in an initial action and the question whether one is entitled to intervene. ${ }^{, 99}$ Persons may intervene in lawsuits only after a court has examined all the justiciability doctrines and determines that it has a genuine case or controversy before it. ${ }^{100}$ Thus, the inquiry should shift to a pragmatic focus on whether the "prospective intervenor has a sufficient stake in the outcome and enough to contribute to the resolution of the controversy to justify his inclusion." dicial machinery has already been mobilized, the consideration should be whether the would-be intervenor's interests could be prejudiced by the pending case's outcome and not whether he has standing to pursue a case of his own.

Supreme Court precedent indicates that it is the party who invokes the court's authority that must demonstrate standing. ${ }^{102}$ Standing, as perhaps the most litigated element of the justiciability doctrine, often plays the pivotal role in determining the court's subject

98. See United States v. Imperial Irrigation Dist., 559 F.2d 509, 521 (9th Cir. 1977), rev’d and vacated on other grounds, 447 U.S. 352 (1980) ("A party seeking to intervene pursuant to Rule 24 ... need not possess the standing necessary to initiate the lawsuit."); Appel, supra note 56 , at 285 ("[T]he basic question of intervention differs from the question of whether the original plaintiff has standing to sue the original defendant, and the addition of an intervenor does not alter the justiciability of the case."); Bandes, supra note 1, at 312 (proposing that intervenors should not be barred from court if the existing litigation already meets the demands of Article III); Tobias, supra note 39, at 443 ("Numerous courts and commentators have convincingly contended that there is little, if any, reason to demand standing of an [intervenor] . . . because the plaintiff has satisfied the case or controversy requirement [and] the judicial machinery has been mobilized ...."); Jack B. Weinstein, Litigation Seeking Changes in Public Behavior and Institutions-Some Views on Participation, 13 U.C. DAVIS L. REV. 231, 241 (1980) ("Since the litigation is already pending, there is less reason to be as finicky about [the intervenor's] standing than there would be if the intervenor was commencing the suit.").

99. Shapiro, supra note 41, at 726. Professor Shapiro's dated exposition of this arguably elementary principle continues to be widely cited. See, e.g., Ruiz, 161 F.3d at 832 (5th Cir. 1998) (repeating Shapiro's language in determining that Article III does not require each and every participant in a case to have standing); Chiles v. Thornburgh, 865 F.2d 1197, 1212 n.16 (11th Cir. 1989) (quoting Shapiro at length for the principle that "[i]ntervention under Rule 24 presumes that there is a justiciable case into which an individual wants to intervene").

100. See Shapiro, supra note 41, at 726 (noting that a court first decides "whether the controversy is ripe ... whether the parties ... are real parties in interest, and whether the interests asserted are sufficient to mobilize the judicial machinery").

101. Id.

102. See Valley Forge Christian Coll. v. Ams. United for Separation of Church \& State, Inc., 454 U.S. 464, 472 (1982) (stating that the party who initiates the lawsuit must show that he personally suffered some injury as a result of the illegal conduct of the defendant). 
matter jurisdiction over the action. ${ }^{103}$ Once the plaintiff has passed this test, "the court's jurisdiction vests .... The presence of additional parties, although they alone could independently not satisfy Article III's requirements, does not of itself destroy jurisdiction already established." ${ }^{104}$ An early Supreme Court decision indicated that "[m]uch less is such jurisdiction defeated by the intervention ... of a party whose presence is not essential to a decision of the controversy of the original parties." ${ }^{, 105}$ By adhering to the rule that the original parties establish jurisdiction, one sidesteps the ramifications of carrying the contrary principle to its natural conclusion, as discussed in Part III.A.2.

2. Requiring Standing for Any Participant in a Lawsuit-Implications for Necessary Joinder and Permissive Intervention. If adding a party without standing destroys a case or controversy, ${ }^{106}$ then those parties joined under Rule 19 should also demonstrate standing, yet no court has so held, including the Eighth and D.C. Circuits. As previously noted, Rule 19(a)(2)(i) has nearly identical language to Rule $24(\mathrm{a})(2)^{107}$ and shares a similar objective of protecting absent parties from having their interests impaired by litigation in which they are not involved. The Rules differ only in how they operate. Under Rule 19 , the original parties have the burden to join nonparties that are necessary to a fair adjudication of their dispute. Rule 24 , by contrast, requires nonparties to initiate their participation if they fear their interests might be impaired by an ongoing lawsuit. ${ }^{108}$ Although the close similarity between the purpose and operation of the two Rules has

103. See, e.g., Flast v. Cohen, 392 U.S. 83, 101 (1968) ("[I]n terms of Article III limitations on federal court jurisdiction, the question of standing is related only to whether the dispute sought to be adjudicated will be presented in an adversary context and in a form historically viewed as capable of judicial resolution."); Chiles, 865 F.2d at 1212 (discussing the role of standing in establishing a court's jurisdiction over a case).

104. Ruiz, 161 F.3d at 832.

105. Wichita R.R. \& Light Co. v. Pub. Utils. Comm'n, 260 U.S. 48, 54 (1922).

106. Obviously, the "case or controversy" between the original plaintiff and defendant reconstitutes itself if the intervenor bows out.

107. See supra note 40 and accompanying text. Although the similarity is noted in the leading treatise on the Federal Rules of Civil Procedure, nothing is made of it. See 7C WRIGHT ET AL., supra note 44, $\$ 1903$ ("The description in Rule 24(a)(2) of persons who are to be allowed to intervene of right is closely related to the description in Rule 19(a)(2)(i) of one of the classes of persons needed for just adjudication.").

108. Martin v. Wilks, 490 U.S. 755, 765 (1989), superceded by statute on other grounds, 42 U.S.C. 1981 (1991) (comparing the operations of the joinder and intervention rules). 
not gone unnoticed, ${ }^{109}$ surprisingly, no court has discussed applying Article III standing to parties added to lawsuits through joinder. Yet, if adding a party without standing to a case or controversy destroys its integrity, then this consequence should befall joined parties as well.

In the same vein, parties that are added to a lawsuit under Rule 24(b), by means of permissive intervention, should also have standing, or else the case or controversy will dissolve. ${ }^{110}$ Permissive intervention may be granted if the "applicant's claim or defense and the main action have a question of law or fact in common." "111 A district court judge has wide discretion in deciding whether permitting the intervention will "unduly delay or prejudice the adjudication of the rights of the original parties." ${ }^{, 12}$ Courts have interpreted Rule 24(b) generously: "the district court can consider almost any factor rationally relevant but enjoys very broad discretion in granting or denying the motion [to intervene]." ${ }^{, 13}$ If the Eighth and the D.C. Circuits are correct-and the Constitution requires that all parties to a lawsuit present a justiciable controversy-then there is no need for Rule 24(b). Permissive intervention exists precisely to accommodate those parties who do not have standing and do not have a sufficient interest to intervene as of right, but for other reasons convincing to the district court should be included in the litigation.

109. Recent decisions note the parallels, but make nothing of it. See, e.g., United States v. Tribal Dev't Corp., 100 F.3d 476, 481 (7th Cir. 1996) ("The language of Rule 24(a)(2) tracks that of Rule 19(a)(2)(i).”); Fed. Deposit Ins. Corp. v. Hyde Park Apartments, No. CV-94-00319GLT, 1996 WL 138558, at *4 (9th Cir. Mar. 27, 1996) (mentioning that the evaluation of whether Rule 19(a)(2)(i) applies to the case "parallels the inquiry under Rule 24(a)"). Following the 1966 amendments to joinder and intervention, courts analyzed the meaning of the close similarities in more depth. See Atlantis Dev't Corp. v. United States, 379 F.2d 818, 823-25 (5th Cir. 1967) (recognizing the similar phrasing and underlying purposes of the two Rules, and analyzing the nonparty's motion to join the lawsuit under both intervention and joinder); John E. Kennedy, Let's All Join In: Intervention Under Federal Rule 24, 57 KY. L.J. 329, 344 (1969) (arguing that the analogous language of the two Rules indicates that courts should consider the policies of Rule 19 in applying Rule 24, namely, the interests of the original parties and judicial efficiency).

110. For an explicit treatment of the intersection of standing with permissive intervention under Rule 24(b) see Amy M. Gardner, An Attempt to Intervene in the Confusion: Standing Requirements for Rule 24 Intervenors, 69 U. CHI. L. REV. 681 (2002).

111. FED. R. CIV. P. 24(b).

112. Id.

113. Daggett v. Comm'n on Governmental Ethics \& Election Practices, 172 F.3d 104, 113 (1st Cir. 1999); see also Purcell v. BankAtlantic Fin. Corp., 85 F.3d 1508, 1513 (11th Cir. 1996) ("[I]t is wholly discretionary with the court whether to allow intervention under Rule 24(b) and even though there is a common question of law or fact, or the requirements of Rule 24(b) are otherwise satisfied, the court may refuse to allow intervention."). 
For example, in Shaw v. Hunt, ${ }^{114}$ two groups of citizens sued the state for racial gerrymandering of a voting district. While the litigation was ongoing, the Supreme Court changed the standing requirements for voters in such challenges. ${ }^{115}$ Under the new standard, some of the voters could not remain as plaintiffs in the case. ${ }^{116}$ Nonetheless, the district court recognized the important contribution the original plaintiffs made to the litigation over the years and granted them permissive intervention. ${ }^{117}$

When unique facts and circumstances exist, such as those described above, permissive intervention gives the district judge discretion to fashion a just party structure. ${ }^{118}$ But if one carries to its logical conclusion the proposition that adding parties without standing to a case destroys federal jurisdiction, then permissive intervention as written is unconstitutional in many cases. Nonetheless, courts in both the D.C. and Eighth circuits apparently see no contradiction in applying Article III standing to a motion to intervene as of right, while using a purely pragmatic approach to grants of permissive intervention. ${ }^{119}$

In sum, it is inconsistent to single out, as have the Eighth and D.C. Circuits, intervention as of right for special treatment. Rule 24(a)(2) is one of several rules by which nonparties without standing may be included in a case. Unless the courts and Congress are prepared to turn back the clock and restrict participants in multiparty

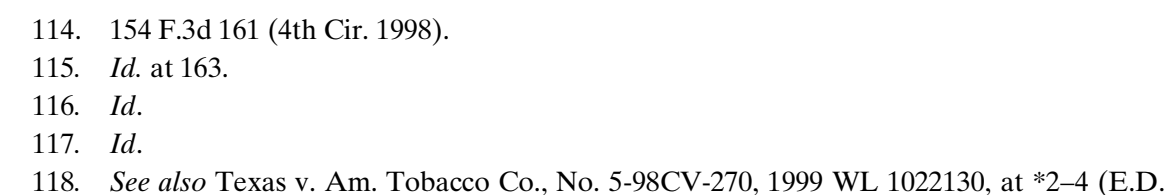
Tex. Nov. 5, 1999) (allowing the governor to intervene permissively in a settlement regarding the award of attorneys' fees to the state's private counsel, even though the court determined that he neither had standing, nor satisfied the criteria for intervention as of right).

119. Standard Heating \& Air Conditioning Co. v. City of Minneapolis, 137 F.3d 567, 570, 573 (8th Cir. 1998) (denying intervention as of right because Article III standing is a prerequisite, but denying permissive intervention because the applicant did not meet the terms of Rule 24(b)); EEOC v. Nat'1 Children's Ctr., Inc., 146 F.3d 1042, 1045-46 (D.C. Cir. 1998) (adopting a generous and flexible interpretation of Rule 24(b) to allow permissive intervention to gain access to materials shielded by a protective order); City of Williams v. Dombeck, No. 00CV66, 2000 WL 33675559, at $* 2$, *4 (D.D.C. Aug. 17, 2000) (noting that a Rule 24(a)(2) interest is equivalent to standing, while permissive intervention is an inherently discretionary enterprise); Nationwide Mut. Ins. Co. v. Nat'l REO Mgmt. Inc., 205 F.R.D. 1, 4-5 (D.D.C. 2000) (granting permissive intervention after finding that the intervenor's interest-seen through the lens of Article III standing_was insufficient). 
litigation only to those with Article III standing, intervenors as of right should not be required to bear the standing burden alone.

\section{B. If Intervenors Want to Act Like a Party, They Must Meet The Same Requirements}

The second rationale for making standing an additional requirement for intervention is that since intervenors want to participate "on equal footing" with the parties they should meet the same standards imposed on the original parties. ${ }^{120}$ "Because an intervenor seeks to become a 'suitor,' and asks the court to 'decide the merits of the dispute," ${ }^{\prime 21}$ which include his own issues, he is no different from a party. Requiring intervenors who want to act like parties to meet the same criteria as parties has a persuasive common sense appeal. ${ }^{122}$

Courts traditionally accorded full party status to intervenors of right, allowing them to file briefs, present witnesses, and participate in all aspects of the litigation. ${ }^{123}$ The plain language of Rule 24(a)-unlike that of 24(b) - does not anticipate conditioning participation of intervenors as of right, ${ }^{124}$ but the Advisory Committee's notes to the 1966 amendments permit courts to curtail their litigation activities where appropriate. ${ }^{125}$ Although such limits are not common, some

120. See supra note 65 and accompanying text.
121. Mausolf v. Babbitt, 85 F.3d 1295, 1300 ( 8 th Cir. 1996).
122. I adopt a variation of this argument in my proposal. If intervenors are seeking relief, 122. I adopt a variation of this argument in my proposal. If intervenors are seeking relief,
then they share the same intent of named parties and should demonstrate standing. See infra Part V.

123. Smith v. Marsh, 194 F.3d 1045, 1051 (9th Cir. 1999) ("As a general rule, intervenors are permitted to litigate fully once admitted to a suit." (quoting League of United Latin Am. Citizens v. Wilson, 131 F.3d 1297, 1304 (9th Cir. 1997))); Solid Waste Agency of N. Cook County v. U.S. Army Corps of Eng'rs, 101 F.3d 503, 508 (7th Cir. 1996) ("An intervenor acquires the rights of a party."); Appel, supra note 56, at 277 (explaining that courts treated intervenors as full parties because the right to intervene was traditionally limited to those who had a close relationship to a case).

124. See Stringfellow v. Concerned Neighbors in Action, 480 U.S. 370, 382 (1987) (Brennan, J., concurring) ("[A] district court has less discretion to limit the participation of an intervenor of right than that of a permissive intervenor."); 7C WRIGHT ET AL., supra note 44, § 1922, at 505 ("Rule 24(a) does not authorize the imposition of conditions and the court, in theory at least, has no discretion to refuse intervention to one who satisfies the requirement of that rule.").

125. "An intervention of right under the amended rule may be subject to appropriate conditions or restrictions responsive among other things to the requirements of efficient conduct of the proceedings." Amendments to Rules of Civil Procedure, 39 F.R.D. 69, 111 (1966) (Advisory Committee's note). 
courts have availed themselves of this option. ${ }^{126}$

Given that intervention can impose substantial costs on the original parties and the judicial process - through complicating the litigation, creating delays, or blocking settlement-courts may be using Article III standing to weed out potentially troublesome intervenors. ${ }^{127}$ If so, it is a particularly blunt instrument for dealing with concerns of judicial efficiency. Expressing perhaps a common fear, a Seventh Circuit opinion paints an unflattering picture of intervenors:

The intervenor seeks control of the suit, acquires a right to conduct the case in a way that may undermine the interests of the original plaintiff (this may, indeed, be the intervenor's principal objective, if the intervenor contends that it has interests adverse to that party) ... It is hard to treat a party such as [this] as a fifth wheel. ${ }^{128}$

Whether they take advantage of it or not, the courts are at liberty to craft the terms under which intervenors may take part in an existing lawsuit. As I propose in Part V, standing should not be used to completely slam the door on intervenors. Rather, the negative aspects of intervention may be minimized through greater use of conditioning participation of intervenors of right.

\section{STANDING AS A GUIDE FOR DETERMINING WHAT CONSTITUTES A "LEGALLY PROTECTABLE INTEREST"}

Article III standing should not be used as a proxy for the interest requirement of Rule 24(a) because the two tests have radically different purposes. Broadly speaking, Article III standing is a test concerning past or imminent harm that is independent of a court's adjudication, while intervention is concerned with preventing speculated harm that may result from court action. In other words, an intervenor

126. Beauregard, Inc. v. Sword Servs. LLC, 107 F.3d 351, 352-53 (5th Cir. 1997) (affirming conditions placed on a Rule 24(a) intervenor because "it is now a firmly established principle that reasonable conditions may be imposed even upon one who intervenes as of right"); Howard v. McLucas, 782 F.2d 956, 961 (11th Cir. 1986) (permitting intervenors to raise only one issue and instructing the district court to narrowly limit discovery accordingly); United States v. Reserve Mining, 56 F.R.D. 408, 420 (D. Minn. 1972) (granting intervention as of right subject to orders regarding the intervenors' participation in a variety of litigation activities).

127. Tobias, supra note 39, at 440 (commenting that many courts have used standing to deny intervention to those that they perceive as intermeddlers). Professor Emma Jones argues that the problem of meddlesome intervenors is overblown, because the expense of litigation helps ensure that those who seek to intervene have a serious interest at stake. See Panel Discussion, Intervention in Public Law Litigation, 13 U.C. DAVIS L. REV. 265, 265 (1980).

128. Bethune Plaza, Inc. v. Lumpkin, 863 F.2d 525, 531 (7th Cir. 1988). 
seeks to protect his interest from harm that has neither occurred nor been threatened, but rather is a possible result of the court's decision in the pending case. By contrast, the plaintiff's injury in the standing context exists independently of the court; it has been allegedly caused or threatened by the defendant. Although a speculative harm would be insufficient for a plaintiff to seek relief from the court, the entire rationale for intervention is to protect nonparties from possible consequences of a court's decision.

If Article III standing is used as the method for testing an intervenor's "interest" under Rule 24(a)(2), legitimate applicants will be blocked from participating, undermining the benefits of the Rule. For example, the Department of Labor brought suit against an exotic dancing establishment, "Heavenly Bodies," for violating the Fair Labor Standards Act. ${ }^{129}$ The liability of Heavenly Bodies turned on whether the exotic dancers were independent contractors or employees. ${ }^{130}$ Two dancers sought to intervene as of right as partiesdefendant to protect their interest in being considered independent contractors. ${ }^{131}$ If the court required the dancers to have standing, they could not have met the Article III burden because it is the government-not the employees - that is injured by violations of federal statutes. ${ }^{132}$ Fortunately, the Seventh Circuit recognized that an adverse ruling against the dancers, i.e., that they were employees, would "deny [them] a certain degree of leverage in negotiating their employment conditions." 133 The court acknowledged that the harm to the dancers "may appear to some [as] speculative"-a concession that would doom an Article III standing inquiry-but allowed the dancers to intervene because there was a possibility that their interests could be impaired as a result of the government's suit. ${ }^{134}$

Likewise, in Cotter v. Massachusetts Association of Minority Law Enforcement Officers, ${ }^{135}$ a group of white police officers sued the City of Boston for race discrimination in its promotion procedures, which they claimed resulted in the advancement of three black sergeants to officer positions at their expense. ${ }^{136}$ The individual black officers, and

129. Reich v. ABC/York-Estes Corp., 64 F.3d 316 (7th Cir. 1995).

130. Id. at 322 .

131. Id. at 320,323 .

132. Id. at 322 .

133. Id. at 323.

134. Id.

135. 219 F.3d 31 (1st Cir. 2000).

136. Id. at 32 . 
a professional association of minority police officers, subsequently moved to intervene alongside the city to defend the contested promotion policies. ${ }^{137}$ On the one hand, if one used Article III standing analysis to determine whether they had an "interest," the black officers' motion would be denied. They have not incurred an injurythey were promoted. Furthermore, the possibility of injury is highly speculative. The court would have to hold not only that the promotion procedures were unconstitutional, but reverse the black officers' promotions as well. On the other hand, as the court ultimately concluded in allowing the officers to intervene, ${ }^{138}$ "to say an officer has no interest in defending his own promotion would be to defy common sense." ${ }^{139}$ Moreover, the court granted the minority association's motion to intervene because it acknowledged that the outcome of the case would likely impact its members in a substantial and concrete manner. ${ }^{140}$

As the situations described above illustrate, nonparties may have quite obvious interests that could be significantly impaired by a court's resolution of a dispute between the named plaintiff and defendant. Clearly, how the court will decide cannot be known at the outset of litigation, so potential impact on interests is by definition speculative. But current standing doctrine rejects speculative injuries. ${ }^{141}$ Thus, courts are sabotaging Rule 24 intervenors' motions if they use standing analysis as a substitute for assessing their interest in a case.

Another difficulty with using standing to inform the interest requirement is that standing doctrine is constantly evolving, and interpretations of the Court's guidance on standing vary widely. ${ }^{142}$ The Court has confessed that "the concept of 'Art. III standing' has not

\footnotetext{
137. Id. at 33 .

138. Id. at 37 .

139. Id. at 35 .

140. Id. at 37. The court recognized that civil rights litigation does not easily fit the classic bipolar model of plaintiff and defendant. "[A]lthough the case may be sparked by a particular episode, the decision may be likely to control an ongoing process" that could affect many others. Id. For the same reasons, Professor Jenkins argues that "the ordinary operation of Rule 24 ... almost always entitles the beneficiaries of affirmative action programs to intervention as of right in suits challenging those programs." Jenkins, supra note 4, at 269 (footnote omitted).

141. See supra notes $25-27$ and accompanying text.

142. See Daggett v. Comm'n on Governmental Ethics \& Election Practices, 172 F.3d 104, 109 (1st Cir. 1999) ("The case law interpreting standing requirements under Article III is, to put it mildly, 'one of the most confused areas of the law." (quoting CHEMERINSKY, supra note 28, at 38)).
} 
been defined with complete consistency in all of the various cases" it has decided. ${ }^{143}$ On the one hand, one commentator viewed Justice Scalia's standing vision in Lujan with its "[i]ndividualized harm, stringent rules of causation and ... demand for near-certain redressability" as erecting a significantly higher barrier to plaintiffs, particularly those representing public interests..$^{144}$ On the other hand, several circuits have characterized standing as a "modest" test. ${ }^{145}$ For example, the Seventh Circuit declared that any interest that could meet the interest requirement of Rule 24(a)(2) "is sufficient to satisfy the Article III standing requirement as well." ${ }^{, 146}$ Incorporating standing doctrine, and all of its attendant confusion and controversy, will hardly bring clarity to applying Rule 24's interest requirement.

\section{REQUIRING STANDING OF INTERVENORS WHO EITHER SEEK OR ARE SUBJECT TO RELIEF}

Several commentators have weighed in on the role-if any-of Article III standing to intervention. With some exceptions, ${ }^{147}$ most argue that Article III standing should have no bearing on intervention. ${ }^{148} \mathrm{I}$ argue that taking sides obscures the issue. A bright-line rule

143. Valley Forge Christian Coll. v. Ams. United for Separation of Church \& State, Inc., 454 U.S. 464, 475 (1982).

144. Gene R. Nichol, The Impossibility of Lujan's Project, 11 DukE EnVTL. L. \& POL'Y F. 193, 201 (2001) (pointing out that the Court's strict approach to the elements of standing is at odds with public law litigation).

145. Daggett, 172 F.3d at 109 (allowing intervention by potential political candidates to defend a state campaign finance law because their interest in the matter met the "rather modest requirements of Article III").

146. Transamerica Ins. Co. v. South, 125 F.3d 392, 396 n.4 (7th Cir. 1997).

147. Appel, supra note 56, at 283, 289 (concluding that the addition of Article III standing to Rule 24(a)(2) is not supported by Supreme Court precedent, but suggesting that it may be a useful way to focus the evaluation of the intervenor's relationship to the litigation); Rodrick J. Coffey, Giving a Hoot About an Owl Does Not Satisfy the Interest Requirement for Intervention: The Misapplication of Intervention as of Right in Coalition of Arizona/New Mexico Counties for Stable Economic Growth v. Department of the Interior, 1998 BYU L. REV. 811, 833 (calling for the Tenth Circuit to reverse its course and "establish Article III standing as the standard by which the interests of applicants for intervention are evaluated"); Cindy Vreeland, Comment, Public Interest Groups, Public Law Litigation, and Federal Rule 24(A), 57 U. CHI. L. REV. 279, 304 (1990) (arguing that associational standing is a useful framework for intervention by public interest groups).

148. See Bullock, supra note 3, at 638-43 (arguing that intervention should be kept separate from standing because standing doctrine is chaotic and does not apply to defendants, and to do otherwise would defeat the policies of Rule 24); Gardner, supra note 110, at 699-702 (proposing that parties be permitted to intervene as long as they satisfy the terms of the Rule and the original parties satisfy Article III); Tobias, supra note 39, at 447-48 (proposing a case-by-case bal- 
implicitly assumes that intervenors are a homogeneous group-nonparties who want to join the plaintiff's cause, demand full participation in the litigation, and seek separate relief. But in fact, as discussed above, defendant-intervenors are quite common, and they may want only to protect an interest rather than seek relief, and might be satisfied with limited participation rather than full rights as parties. ${ }^{149}$ Accordingly, requiring Article III standing of intervenors should depend on the intent of the intervenor-does he seek relief (or could he be subject to such relief), or is he seeking to protect an interest?

On the one hand, if a plaintiff-intervenor had a claim for relief (or as a defendant-intervenor could be subject to such claims), then the plaintiff-intervenor should be required to demonstrate standing (or, in the case of the defendant-intervenor, demonstrate a case or controversy against an original plaintiff with standing). For example in United States v. LTV Steel Company, ${ }^{150}$ the Group Against Smog and Pollution (GASP) sought intervention in a government suit against a coke production plant for air emissions violations in order to obtain relief for GASP members living in the area. ${ }^{151}$ GASP also sought to participate in discovery, testifying, presenting evidence, and cross-examining witnesses. ${ }^{152}$ In such a case, where the intervenor easily steps into the shoes of a party-plaintiff, requiring standing is reasonable. ${ }^{153}$

On the other hand, if an intervenor seeks only to protect an interest, is not pursuing his own claim, is not subject to a claim, and is willing to have his participation conditioned, then he should not have to demonstrate a case or controversy as to himself. ${ }^{154}$ Keeping with

ancing test of the applicant's potential contribution to the merits of the case versus the costs to the judicial system of adding parties).

149. Both Reich v. ABC/York-Estes Corp. and Cotter v. Massachusetts Ass'n of Minority Law Enforcement Officers involved defendant-intervenors seeking to protect their interests rather than requesting relief. See supra notes 129-39 and accompanying text; see also George M. Strickler, 64 TUL. L. REV. 1557, 1587 (1990) ("Those who seek to intervene as defendants often will not be seeking any affirmative relief for themselves and, far from alleging that injury to them is certain, typically will contend that the plaintiffs are not entitled to relief.").

150. 187 F.R.D. 522 (E.D. Pa. 1998).

151. Id. at 524 .

152. Id.

153. Interestingly, although the Third Circuit has not addressed the circuit split, the district court in this case did engage in a standing analysis, and found that GASP passed the test. Id. at 525-26.

154. But $c f$. Am. Law InST., Federal Judicial Code Revision Project, Tentative DRAFT No. 2, at 50-51 (1998) (likening defendant intervenors who seek to protect their interests to parties in a declaratory judgment action who do have a justiciable controversy between 
the environmental theme, Herdman v. Town of Angelica ${ }^{155}$ involved a citizens' group that had worked closely with the town to draft and pass a local ordinance that restricted construction and operation of solid-waste facilities in the area. ${ }^{156}$ Then, when a company that wanted to construct such a facility challenged the constitutionality of the law, the citizens' group sought to intervene to assist the town in defending it. ${ }^{157}$ The district court rigorously applied Rule 24(a)(2), but correctly did not require justiciability as to those defendant-intervenors who sought to protect a variety of interests ${ }^{158}$ but were not seeking, or were not the potential targets of, separate relief. ${ }^{159}$

For those concerned that such an approach would open the floodgates to interest-intervenors, the courts have two tools at their disposal: the discretion to condition the participation of intervenors, ${ }^{160}$ and denial of intervention when the intervenors' interest is already adequately represented by an existing party. ${ }^{161}$

Depending on the nature of an intervenor's interest, a court may weigh whether he should be permitted to contest all the issues and enjoy all the prerogatives of a party litigant. ${ }^{162}$ For example, a court may limit the issues an intervenor may raise. ${ }^{163}$ A judge may permit

\footnotetext{
each other).

155. 163 F.R.D. 180 (W.D.N.Y. 1995).

156. Id. at 183 .

157. Id. at $182-83$.

158. The citizens' group had three interests: preserving the health and safety of the community; maintaining the legislation; and preserving the integrity of a separate administrative proceeding it had initiated regarding the issuance of the permit to the landfill company. Id. at 183 .

159. The district court did not raise the issue of limiting the participation of the citizens' group. It is likely that the group's participation would have been quite significant, because it successfully argued that the town had limited financial resources to defend the litigation and was less committed to the constitutional issues at stake. $I d$. at 190.

160. See supra note 125 and accompanying text; Vreeland, supra note 147, at 307-08 (arguing that "[1]imited intervention is a useful tool because it allows courts to incorporate the benefits of intervention yet minimize complications, delays, and added expenses" (footnote omitted)).

161. FED. R. CIV. P. 24(a)(2).

162. Smuck v. Hobson, 408 F.2d 175, 179-80 (D.C. Cir. 1969) (rejecting a focus on the "interest" test of Rule 24, and favoring a pragmatic approach that looks at adequacy of representation and explores ways to condition participation).

163. See, e.g., Sierra Club v. Martin, No. Civ. A. 1:96-CV-926, 1996 WL 452257, at *3 (N.D. Ga. June 17, 1996) (granting intervention as of right to the extent the intervenors sought to defend the plaintiff's claims but not for purposes of seeking cross-claims or counterclaims); Wilder v. Bernstein, No. 78 CIV. 957, 1994 WL 30480, at *4 (S.D.N.Y. Jan. 28, 1994) (limiting intervenors "to their stated purpose" and barring relitigation of issues decided in earlier proceedings and not raised by the existing plaintiffs).
} 
intervention for specific motions, ${ }^{164}$ and may curtail an intervenor's presentation of evidence or participation in discovery. ${ }^{165}$ Where multiple intervenors are involved, a court may require that they choose a representative spokesperson and combine discovery and motion requests. ${ }^{166}$ Thus, courts have a whole host of options for proactively limiting the potential disruption to an ongoing case by the addition of an intervenor, without blocking his participation completely.

Furthermore, courts are adept at disposing of motions to intervene on the basis that the applicant's interest is already "adequately represented by the existing parties." ${ }^{167}$ Despite the Supreme Court's holding that the burden of showing inadequacy of representation should be minimal, ${ }^{168}$ it still is used to winnow out intervenors perceived as meddlesome. In fact, tests of "inadequacy" tend to vary depending on the strength of the interest. ${ }^{169}$ "Courts might require very little 'inadequacy' if the would-be intervenor's home were at stake and a great deal if the [intervenor's] interest was thin and widely shared,"

For example, in Chiles v. Thornburgh ${ }^{171}$ Dade County sued the United States for its practice of housing alien felons with nonviolent

164. W. Res., Inc. v. Union Pac. R.R. Co., No. 00-2043-CM, 2001 WL 1718370, at *6 (D. Kan. Sept. 12, 2001) (granting an intervenor's motion to intervene for the unique and limited purpose of filing a motion for a protective order with regard to disclosure of private and confidential contracts).

165. Southern v. Plumb Tools, 696 F.2d 1321, 1323 (11th Cir. 1983) (holding that the district court erred in not preventing the plaintiff-intervenor from testifying to the jury that the plaintiff had received worker's compensation benefits for his injury). In United States v. Duke Energy Corp., 171 F. Supp. 2d 560 (M.D.N.C. 2001), the court held that "[a]pplicants have an unconditional right to intervene, but this does not prevent the imposition of reasonable limitations on Applicants' participation to ensure the efficient adjudication of the litigation." Id. at 565. It suggested that the magistrate judge might limit the three public interest environmental groups' involvement in ongoing discovery as well as their ability to initiate independent discovery. Id.

166. Sierra Club, 1996 WL 452257 , at $* 5$ (suggesting that the three separate defendantintervenors and the defendants consolidate discovery in order to reduce the legal expenses for all parties).

167. FED. R. CIV. P. 24(a)(2).

168. Trobovich v. United Mine Workers, 404 U.S. 528, 538 n.10 (1972) ("The requirement of the Rule is satisfied if the applicant shows that representation of his interest 'may be' inadequate; and the burden of making that showing should be treated as minimal.").

169. United States v. Hooker Chems. \& Plastics Corp., 749 F.2d 968, 983 (2d Cir. 1984) ("A showing that a very strong interest exists may warrant intervention upon a lesser showing of impairment or inadequacy of representation. Similarly, where representation is clearly inadequate, a lesser interest may suffice as a basis for granting intervention.").

170. Daggett v. Comm'n on Governmental Ethics \& Election Practices, 172 F.3d 104, 112-13 (1st Cir. 1999).

171. 865 F.2d 1197 (11th Cir. 1989). 
alien detainees at the Krome federal detention facility in Dade County, Florida. ${ }^{172}$ Two separate groups sought to intervene: several Krome detainees and individual homeowners living near the facility. ${ }^{173}$ On the one hand, the Eleventh Circuit held that Dade County might not adequately represent the plight of the aliens at Krome if its main concern was the safety of nearby homeowners, and therefore permitted the detainees' motion. ${ }^{174}$ On the other hand, the court denied intervention to the homeowners, because it found that they shared an identical interest adequately represented by Dade County-prevention of riots and escapes from Krome into the surrounding community. ${ }^{175}$ Thus, the court was able to control the number of parties to the litigation by evaluating adequacy of representation, instead of by applying the more restrictive Article III standing test.

In sum, the circuit split over whether intervenors should demonstrate Article III standing-either as an additional test or as a way to prove their Rule 24(a) "interest"-masks the real issue. In evaluating motions to intervene, courts should analyze the intervenor's intent, and based on this determination, Article III standing may or may not be an appropriate requirement. If an intervenor looks like a party (because he is requesting or blocking relief) and wants to act like a party (by participating in all aspects of litigation), then it is only reasonable that the plaintiff-intervenor show standing, or that the defendant-intervenor has a justiciable case with the original plaintiff. But, if the intervenor merely seeks to protect an interest that might be impaired by existing litigation, standing doctrine is misplaced. Imposing a standing requirement is particularly inappropriate as a method for preventing intervenors from joining a lawsuit in the interests of judicial efficiency, because courts have other weapons at their disposal, such as conditioning the intervenors participation, or finding that their interests are already adequately represented.

\section{CONCLUSION}

The underlying purpose of intervention is not being served by the current application of Rule 24 in some federal courts of appeals. First, the Eighth and D.C. Circuits have ignored the logical consequences of insisting that any party without standing that becomes in-

172. Id. at $1200,1214$.

173. Id. at 1201 .

174. Id. at 1215 .

175. Id. 
volved in a litigation automatically destroys federal court jurisdiction over a case. To be consistent, courts would also have to require standing of parties who seek to intervene permissively or to be joined. Since neither any court nor the Rules drafters have ever suggested that standing should be required in the latter circumstances, it raises serious doubts as to how it can be justified for intervenors under Rule 24(a)(2).

Second, there is no sensitivity to the fact that most intervenors seek to enter litigation on the defendant's side. Not surprisingly, then, applying a plaintiff-focused doctrine like standing to defendantintervenors is counterproductive. While a showing of only "speculative harm" automatically destroys a plaintiff's standing, the core principle of intervention is to protect an intervenor's interests from speculated harm from a court's action in the existing case. Since the tests operate in contradiction to one another, it makes no sense to use one to inform the other.

Third, the courts of appeals have generally assumed that all intervenors want to be full parties and thus have not fully exploited their discretion to condition intervenors' participation, preferring instead to use standing to block their involvement completely. It is fair to surmise that given the choice between being barred from a case completely and being allowed some limited participation, intervenors with an interest to protect would gladly acquiesce to the latter. Applying standing as a way to reduce litigation complexities or remove supposed intermeddlers solves too much. However, when intervenors seek specific relief against one of the parties, and insist on full party rights, they begin to closely resemble the role of plaintiffs, and requiring standing is reasonable.

Given the disparate goals of intervenors and their differing degrees of desired participation in a lawsuit, it is impractical to have a one-size-fits-all rule regarding standing's relationship to intervention. It is time for courts to realign their application of Rule 24 with its objective of bringing in nonparties whose interests may be at risk in a pending litigation. Courts should avail themselves of their discretion to condition intervenors' participation to ensure manageability of the litigation and minimize prejudice to the existing parties. Likewise, in those few cases when intervenors seek a form of relief and want to litigate as full parties they should meet Article III standing requirements. 